\title{
DECOLORIZATION OF DYES FROM TEXTILE WASTEWATER USING BIOCHAR: A REVIEW
}

\author{
Hadas Mamane* \\ School of Mechanical Engineering, Faculty of Engineering, Tel Aviv University \\ Tel Aviv 69978, Israel, hadasmg@tauex.tau.ac.il \\ (D) https://orcid.org/0000-0001-5321-4342 \\ Shir Altshuler \\ School of Mechanical Engineering, Faculty of Engineering, Tel Aviv University \\ Tel Aviv 69978, Israel \\ Elizaveta Sterenzon \\ School of Mechanical Engineering, Faculty of Engineering, Tel Aviv University \\ Tel Aviv 69978, Israel \\ Vinod Kumar Vadivel \\ School of Mechanical Engineering, Faculty of Engineering, Tel Aviv University \\ Tel Aviv 69978, Israel \\ https://orcid.org/0000-0003-4986-4929
}

\begin{abstract}
The textile industry is one of the largest in many low and middle-income countries, especially in Asia, second only to agriculture. Textile wastewater is discharged into the environment due to the lack of affordable and sustainable solutions to adsorb or remove the dye from the water. Biochar is generated by pyrolysis of organic material from plant waste in low-oxygen conditions, and is considered carbon-negative. Biochar for dye adsorption in textile wastewater effluent was proven to be highly effective. However, adsorption efficiency varies with experimental parameters, therefore there is a gap in application especially in small dye houses. Efforts should be made to find innovative and affordable solution to make the textile industry more sustainable, by developing methods for collection and reuse, recycle and upcycle of textile waste, by reducing the consumption of water, energy and chemicals and by developing methods for treatment of the textile wastewater.
\end{abstract}

\section{Keywords}

textile dye effluent; biochar; wastewater; sustainability; contamination; sorption

\section{Introduction}

Climate change, population growth, rising standards of living and uneven distribution of water are the main causes for competition over water resources, water scarcity, poor water quality and variability of hydrological events. Water is the core of sustainable development and unfortunately, water is not equally available and in many areas around the world clean water is out of reach [1]. The environmental stress on water bodies is evident in terms of not only quantity, but also quality. Globalization of industrialization has resulted in high pollution of water resources worldwide. The major industries responsible for pollution are the dyeing industries, paper industries, tanneries, metal-plating industry, mining operations, fertilizer industries, agricultural waste and pesticides. The demand for water in the industrial sector is expected to increase by $283 \%$ during the first half of the $21^{\text {st }}$ century [2], resulting in increasing industrial wastewater discharge.

\section{Discussion}

The textile industry is one of the largest in many low and middle-income countries, especially in Asia [3]. The textile industry is one of the cornerstones in economies of many countries [4]. For example, the Indian textile industry according to the India Brand Equity Foundation (IBEF), it is the second largest industry, after agriculture, providing employment to over 45 million people directly and 60 million people indirectly, and it contributes $14 \%$ of the Indian total industrial production [5]. Humans are aesthetically interested in dyed textile, therefore the use of dyes in textile will not be abandoned. Different types of dyes are used in a variety of industries including the food industry, textile, tanneries, plastics and pharmaceuticals. Many products in those industries contain 
several dyes from different chemical classes resulting in a complex wastewater [6]. Industrial dyes, in particular used in the textile industry, have complex molecular structures, synthetic in origin and recalcitrant [7].

Most of the chemicals are added in the dyeing process where a color is added to the dye baths, the fabric is immersed in the dye baths until the dye is fixed. In some cases, there is a need to add salt to the bath in addition to the color in the coloring processes to increases the affinity of the color to the fabric [8]. Over $7 \times 10^{5}$ tons of synthetic dye are produced annually, with 10-15\% of it not ending up in the final product [4] thus eventually further contaminating the environment.

Therefore the effluent also contains a large amount of recalcitrant unfixed dyes (as acid dyes, basic dyes, sulfur dyes, chrome dyes, optical/fluorescent brightener and azoic dyes) as the dyes are not totally fixed to the fiber of different textiles during the dyeing process (fibers as wool and nylon, cotton and viscose, polyester and acrylic). The textile industry requires a large amount of water for the production process, and is also one of the major producers of wastewater that can have carcinogenic and mutagenic compounds [9]. Wastewater from the textile industry is frequently discharged directly into lakes and rivers without any proper treatment and often these water sources are used by locals domestically $[10,11]$. Since the dyeing process uses a significant amount of water, recycling used in the dyeing process can conserve water, however it requires treatment whether recycled or discharged to the environment. Reference values for water reuse in textile industry, included COD between $60-80 \mathrm{mg} / \mathrm{L}$, conductivity of $1000 \mu \mathrm{S} / \mathrm{cm}$ and dissolved solids up to $500 \mathrm{mg} / \mathrm{L}$ [11]. In addition to dyes, the textile industry's wastewater contains also salts, acids and alkalis, oxidizers and recyclers, heavy metals, lubricating oils and fibers [11].

Dyes cannot be removed through conventional treatment unit operations due to the complex characteristics of the wastewater as high solubility, non-degradable nature, diversity and often changing speciation in water. When industrial wastewater is discharged into natural water bodies it can result in hazardous effects on the living systems because of the carcinogenic, mutagenic, allergenic and toxic nature of dyes [6]. This is a paradox as current conventional and advanced methods for the removal or degradation of persistent and emerging textile contaminants are limited, since they often involve intensive capital, lack of adaptive technological tools, social barriers and emphasis on centralized systems. Consequently, to close the gap, there is a dire need for innovative solutions and for widespread decentralized systems in the textile industry suitable for rural areas and capitalchallenged countries.

There are many treatment methods when dealing with textile wastewater. The different techniques can be based on physical (sedimentation, filtration, floatation, coagulation, reverse osmosis, solvent extraction, adsorption, incineration, and distillation), chemical (neutralization, reduction, oxidation, catalysis, ion exchange, electrolysis) and biological (stabilization, aerated lagoons, trickling filters, activated sludge, anaerobic digestion) [12]. Physical methods are very common methods in textile wastewater treatment due to their high color removal efficiency, especially adsorption, filtration and membrane filtration. Other treatment processes as reverse osmosis, nanofiltration and multiple effect evaporators are effective but expensive, while the common treatment methods are non-destructive, lower in cost, time-consuming and less efficient [13].

Adsorption by porous materials is one of the most promising and affordable techniques for the removal of dissolved pollutants, serving as an alternative to energy-intensive technologies [14]. Activated carbon is a widely used adsorbent, but biochar, which is inexpensive, abundant and may have comparable adsorption capacity, can be used as an affordable alternative [15-17]. However, the efficiency, local manufacturing, availability and costs must be examined. Biochar is the result of low-temperature pyrolysis of carbon-rich biomass (from agricultural and forestry wastes) under low-oxygen conditions [18]. As can be seen in Fig. 1, there is an increase in the number of publications using the keywords: dye sorption, textile wastewater and biochar (by google scholar). 


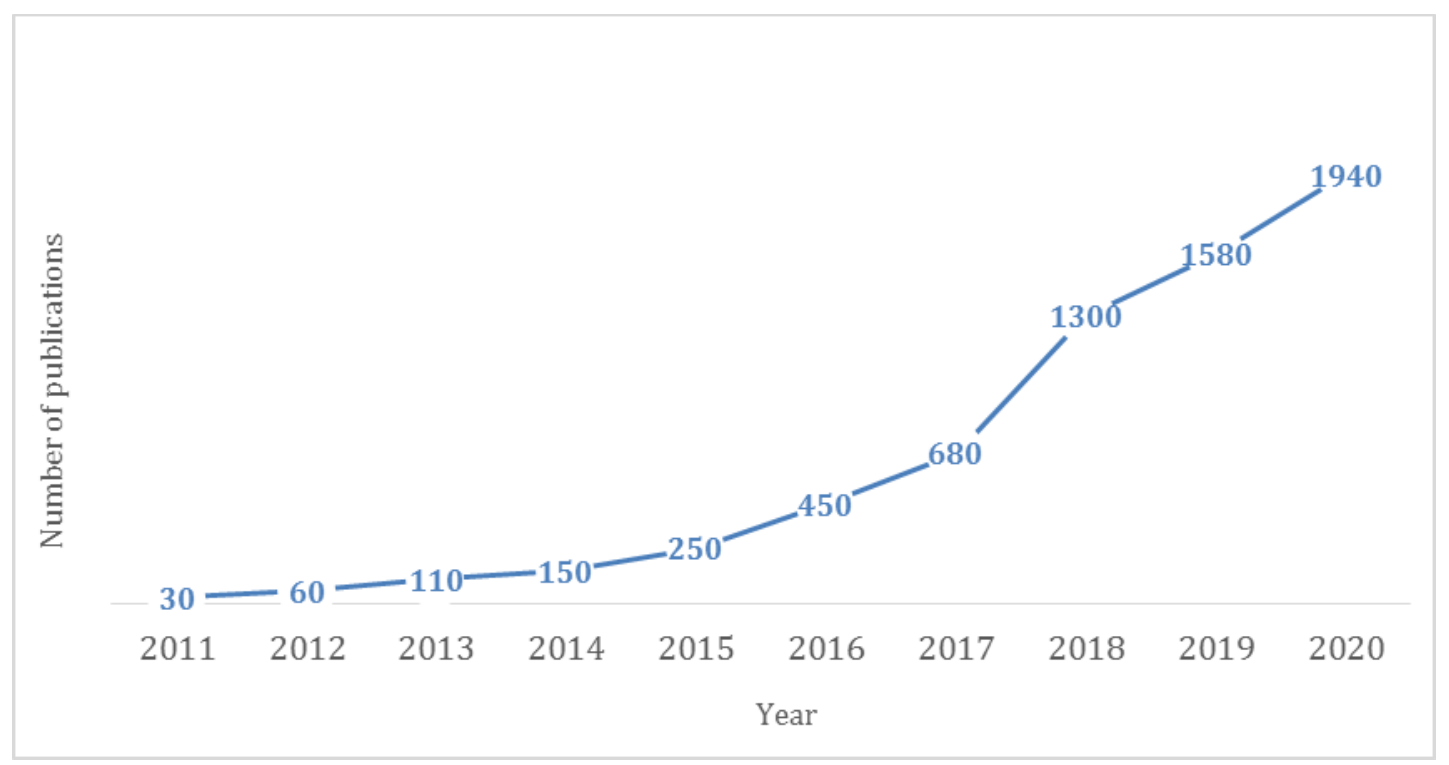

Fig. 1. Yearly number of publications using the keywords: dye sorption, textile wastewater and biochar (by google scholar)

The biochar created is a stable carbon black solid that is highly porous with large surface area (Fig. 2.). More than 70 percent of its composition is carbon [19]. The biochar's chemical composition varies with feedstocks used to make it and methods used to heat the biomass. The pyrolysis process varies as it can be done with different conditions as burning temperature and burning time, reactor volume, other gasses and materials in the reactor [20]. However, different thermochemical processes can be also used for biochar production [18]. Compared to activated carbon, biochar can be created from various types of biomass, requires less energy in the production process and consequently can provide a solution in the treatment of textile wastewater in poor income countries.

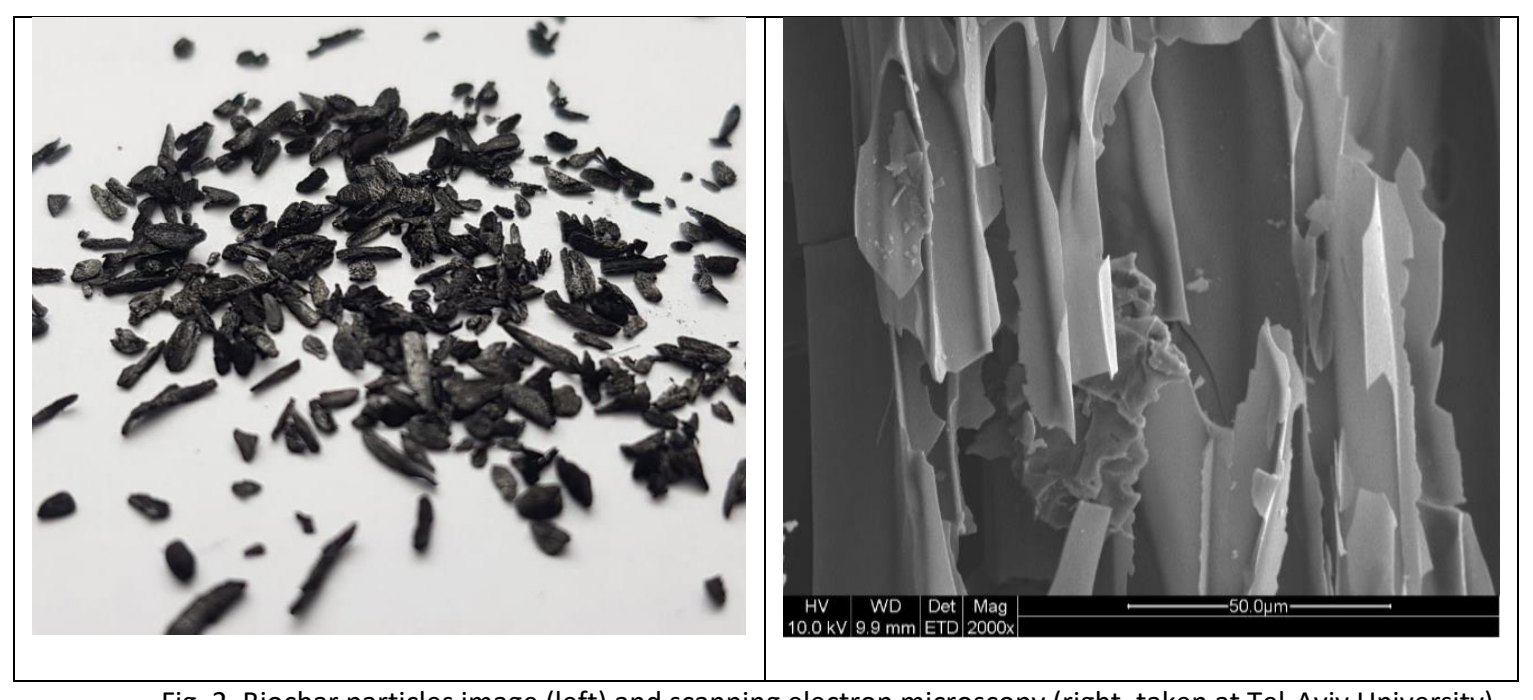

Fig. 2. Biochar particles image (left) and scanning electron microscopy (right, taken at Tel-Aviv University) 
The porosity and high surface area of biochar make it an excellent adsorbent of organic contaminants and heavy metals in wastewater [17]. This has led to a growing interest in using biochar for water treatment, although most research today focuses on its abilities for soil fertilization [15]. Adsorption of textile dyes was examined with various biochar types $[15,21,22]$. For each type of dye, the biochar type, process parameters (temperature, $\mathrm{pH}$, agitation time) and wastewater quality influence the efficiency of the dye removal from the wastewater. Most studies have focused on the removal of pure, highly concentrated dye solutions that do not represent the actual effluent from real dye houses. Real effluent may contain lower dye concentrations and additional substances as previously mentioned, such as salts, detergents, solids, and fiber residuals, which have a tremendous effect on the biochar's sorption capacity.

There are numerous types of dyes and biochars - and therefore the biochar type and dose should match the dye type. The major anionic dyes are the acid and reactive dyes, and the most problematic ones are the brightly colored, water-soluble acid dyes [23]. Acid dyes are a sub-group of anionic dyes and are called so, because they are usually applied to the fibers in acid solutions [24]. Cationic dyes are dyes that can be dissociated into positively charged ions in the aqueous solution, and the cationic dye dyes the fiber through the binding of its cation ion [7,23]. Basic dye, are highly visible and have high brilliance and intensity of colors [25].

As mentioned above, the textile industry uses different colors, each with its own properties and characteristics. Moreover, the biochar itself can vary based on the initial biomass from which it is produced. In order to find the best biochar-dye combination, a summary of articles examining different combinations was made [26-43]. In these articles, the biochar efficiency in removing the dye from a mixture was calculated using mass balance equation for dye adsorption on biochar [37].

Table 1 summarizes different characteristics from 18 articles that present the use of biochar in treatment of textile wastewater [26-43]. The articles are catagorized to biochar properties, dye properties, experimental conditions, dye adsorption experiments compared to a common biochar and modified biochar. All the experiments presented were batch experiment in a controlled environment. From the table it is evident that there are some differences between the treatment requirements for cationic dyes and anionic dyes. The adsorption of the dye to the biochar depend on the characteristics of the solution, the type of the biochar and the conditions in which the experiment was performed.

One of the critical conditions is the solutions $\mathrm{pH}$, where the adsorption of cationic dyes will be maximized when the $\mathrm{pH}$ of the solution is basic and anionic dyes in acidic $\mathrm{pH}$, with preferred $\mathrm{pH}$ at 3-4. The $\mathrm{pH}$ of the solution has a significant effect on the interaction of the dyes with the biochar in the adsorption process. For example, the effects of the solutions $\mathrm{pH}$ were examined on the adsorption of three dyes, Methyl Orange, an anionic dye and Malachite green \& Methylene blue, both cationic dyes and three types of biochar, each produced with a different solvent (acetone, ethanol and methanol) [30]. The adsorption of the cationic dye Malachite Green onto the biochar increased with the increase in $\mathrm{pH}$. The solution $\mathrm{pH}$ influenced the adsorption through dissociation of functional groups on the active sites of the biochar. In another study, the adsorption of anionic dye Reactive Red 141 onto a Pecan Nutshell based biochar occured mostly in an acidic environment with a low pH [32]. Under acidic conditions, the biochar surface is positively charged whereas the Reactive Red 141 has several sulfonated groups, which are negatively charged that are attracted to the biochar surface, increasing the dye removal percentage.

The dye to biochar interaction depends on the temperature of the mixture, the interaction time, the steering speed and more. Almost all the experiments showed that a temperature of $25-30^{\circ} \mathrm{C}$ is the optimal temperature for the dye's adsorptions. A higher or lower temperature can affect the dye particles' velocity in the mixture and will reduce the adsorption [27]. This result is significant because it means the treatment will not require any major heating or cooling systems and the treatment can be effective in real wastewater. The interaction time is also a crucial parameter. With short interaction time, the dye will not be able to sufficiently interact with the biochar, while with long interaction time, the binding between the dye and the biochar could become loose, and the biochar can undergo modifications that can damage its functionality and even release material and pollutants to the water and cause more damage $[27,30,34]$. Each biochar-dye combination has its own optimal interaction time depending on the biochar and dye's structure and concentrations and on the other conditions regulating 
the environment. Mubarak et. al. showed an increase in removal effecincy with contact time of methylene blue (cationic) and orange-G (anionic) onto Empty fruit bunch based biochar [36]. Another factor that can affect the interaction is the rotation speed of the mixture. A high rotation speed can lead to a high shear stress that can break the bindings between the biochar and the dye and can even damage the biochar particles and thus lower its efficiency. The most common rotation speed as presented in Table 1, is $\sim 130-150 \mathrm{rpm}$.

Several studies attempted to increase an existing biochar activity by performing different modifications on it as Iron impregnation biochar, addition of cationic surfactant to the biochar surface, inserting magnetic formation to the biochar and more. These new characteristics provide the biochar with a stronger affinity and interaction between the biochar and the dye. One example of the benefits of these modifications used Rice Husk derived biochar mixed with a solution containing an aqueous phase reduction of ferrous iron $\left(\mathrm{FeSO}_{4} \times 7 \mathrm{H}_{2} \mathrm{O}\right) \mathrm{called} \mathrm{nZVI}$, resulting in attachment of nanoscale zero-valent iron particles to the biochar creating a modified biochar (nZVI/BC) to adsorb the anionic dye Methyl Orange. In this experiment, three types of biochar various theoretical mass ratios of $\mathrm{nZVI} / \mathrm{BC}$ at 1:3, 1:5, and 1:7 [28]. The $\mathrm{nZVI} / \mathrm{BC} 1: 5$ adsorbed almost $100 \%$ of the dye in the mixture compared to the other modified biochars that peaked at $90 \%$ and the non-modified biochar that reached only $10 \%$. Although there may be an advantage in using modified biochar, there might be a problem after extended usage. For example, high concentrations of oxygen can convert the Feo molecules into ferrous or ferric oxide leading to a passivation layer forming on the $\mathrm{nZVI}$ surface.

Table 1. A summary of articles presenting biochar source, postproduction modifications, dye type, optimal conditions and experimental results

\begin{tabular}{|c|c|c|c|c|c|c|c|c|c|c|}
\hline \multirow{2}{*}{$\begin{array}{l}\text { Biochar } \\
\text { Source }\end{array}$} & \multirow{2}{*}{$\begin{array}{c}\text { Biochar } \\
\text { preparation }\end{array}$} & \multirow{2}{*}{$\begin{array}{l}\text { Postproduction } \\
\text { Modifications }\end{array}$} & \multirow[t]{2}{*}{ Dye } & \multicolumn{4}{|c|}{ Optimal Condition } & \multirow{2}{*}{\multicolumn{2}{|c|}{ Results }} & \multirow{2}{*}{$\begin{array}{c}\text { Refere } \\
\text { nce }\end{array}$} \\
\hline & & & & pH & $\begin{array}{c}\text { Temp } \\
\left({ }^{\circ} \mathrm{C}\right)\end{array}$ & RPM & $\begin{array}{c}\text { Contact } \\
\text { time } \\
\text { (min) }\end{array}$ & & & \\
\hline $\begin{array}{l}\text { Spent } \\
\text { mushroom } \\
\text { substrate } \\
\text { (SMS) }\end{array}$ & $\begin{array}{l}\text { Pyrolysis at } \\
450^{\circ} \mathrm{C} \text { for } 4 \\
\text { hours }\end{array}$ & $\begin{array}{l}200 \mathrm{~cm}^{3} \mathrm{STP} / \mathrm{min} \text { of } \\
\mathrm{N}_{2} \text { was fed into the } \\
\text { reactor, and steam } \\
\text { was used as the } \\
\text { activation agent at } \\
800^{\circ} \mathrm{C} \text { for } 2 \mathrm{~h} \text {. } \\
\text { Modification goals: } \\
\text { Enhancement of } \\
\text { the biochar's } \\
\text { textural properties. }\end{array}$ & $\begin{array}{l}\text { Congo Red } \\
\text { (CR) } \\
\text { (anionic) } \\
\text { Crystal } \\
\text { Violet (CV) } \\
\text { (cationic) }\end{array}$ & $\begin{array}{l}\text { CR:4 } \\
\text { CV:6 }\end{array}$ & 30 & 150 & $\begin{array}{l}\text { CR:750 } \\
\text { CV:1000 }\end{array}$ & $\checkmark$ & $\begin{array}{l}\text { Color and COD } \\
\text { removal } \\
\text { efficiencies up } \\
\text { to } 99.6 \% \text { and } \\
67.7 \% \text { for CV. } \\
\text { Color and COD } \\
\text { removal } \\
\text { efficiencies up } \\
\text { to } 10.3 \% \text { and } \\
23.7 \% \text { for } \mathrm{CR} \text {. }\end{array}$ & [41] \\
\hline $\begin{array}{l}\text { Rice husk } \\
\text { (RHB) and } \\
\text { Coir pith } \\
\text { (CPB) }\end{array}$ & $\begin{array}{c}\text { Pyrolysis at } \\
700^{\circ} \mathrm{C} \text { for } 5 \\
\text { hours }\end{array}$ & $\begin{array}{l}\mathrm{RHB} \text { or } \mathrm{CPB} \text { were } \\
\text { added to a solution } \\
\text { containing Fe } \\
\left(\mathrm{NO}_{3}\right)_{3} \cdot 9 \mathrm{H}_{2} \mathrm{O} \\
\text { dissolved in water. } \\
\text { The mixture was } \\
\text { oven dried at } 105 \\
{ }^{\circ} \mathrm{C} \text { for one day, } \\
\text { followed by } \\
\text { calcination at } 500 \\
{ }^{\circ} \mathrm{C} \text { for } 4 \mathrm{~h} \text {. } \\
\text { Modification goals: } \\
\text { Provide the biochar } \\
\text { with oxidizing } \\
\text { properties. }\end{array}$ & $\begin{array}{l}\text { Acid Red } 1 \\
\text { (AR1) }\end{array}$ & 3 & $30-50$ & 150 & 120 & $\begin{array}{l}\checkmark \\
\checkmark\end{array}$ & $\begin{array}{l}\text { Maximum dye } \\
\text { removal for Fe- } \\
\text { RHB was } 97.6 \% \text {. } \\
\text { Maximum dye } \\
\text { removal for Fe- } \\
\text { CPB was } 99.1 \%\end{array}$ & [27] \\
\hline Rice husk & $\begin{array}{c}\text { Pyrolysis at } \\
500^{\circ} \mathrm{C}\end{array}$ & $\begin{array}{l}\text { Biochar was mixed } \\
\text { with } \mathrm{HCl} \text { for } \\
\text { demineralization } \\
\text { then mixed with } \\
\text { different mass } \\
\text { ratios of } \mathrm{nZVI} \text {. }\end{array}$ & $\begin{array}{l}\text { Methyl } \\
\text { orange } \\
\text { (anionic) }\end{array}$ & 4 & 25 & - & 15 & $\checkmark$ & $\begin{array}{l}\text { Maximum dye } \\
\text { removal for } \\
\text { nZVI at 5:1 was } \\
98.5 \% \text {. } \\
\text { Removal } \\
\text { capacity of } \\
97.8 \text {, }\end{array}$ & [28] \\
\hline
\end{tabular}

https://doi.org/10.32933/Actalnnovations.37.3•ISSN 2300-5599 • (C) 2020 RIC Pro-Akademia - CC BY 


\begin{tabular}{|c|c|c|c|c|c|c|c|c|c|}
\hline & & $\begin{array}{l}\text { Modification goals: } \\
\text { increase dye } \\
\text { adsorption by } \\
\text { transforming it to } \\
\text { low molecular } \\
\text { weight products } \\
\text { through } \\
\text { destruction of its } \\
\mathrm{N}=\mathrm{N} \text { bonds. }\end{array}$ & & & & & & $\begin{array}{l}306.7,605.0, \\
\text { and } 709.1 \\
\mathrm{mg} / \mathrm{g} \text { for initial } \\
\text { concentrations } \\
\text { of } 60,200,400, \\
\text { and } 600 \mathrm{mg} / \mathrm{L}, \\
\text { respectively. }\end{array}$ & \\
\hline $\begin{array}{l}\text { Bael shell } \\
\text { (BS) }\end{array}$ & $\begin{array}{l}\text { Pyrolysis at } \\
500^{\circ} \mathrm{C} \text { for } 3 \\
\text { hours }\end{array}$ & $\begin{array}{c}\text { The biochar did not } \\
\text { undergo any } \\
\text { special } \\
\text { modifications }\end{array}$ & $\begin{array}{c}\text { Patent } \\
\text { blue (PB) } \\
\text { (Anionic) }\end{array}$ & 2.7 & - & 110 & 60 & $\begin{array}{ll}\checkmark & \text { Maximum dye } \\
\text { removal was } \\
74 \%(3.7 \mathrm{mg} / \mathrm{g})\end{array}$ & [21] \\
\hline $\begin{array}{l}\text { Carboxym- } \\
\text { ethyl } \\
\text { cellulose } \\
\text { (CM) from } \\
\text { raw chicken } \\
\text { manure }\end{array}$ & $\begin{array}{l}\text { Pyrolysis at } \\
600^{\circ} \mathrm{C} \text { for } 2 \\
\text { hours }\end{array}$ & $\begin{array}{l}\text { The biochar did not } \\
\text { undergo any } \\
\text { special } \\
\text { modifications }\end{array}$ & $\begin{array}{l}\text { Methyl } \\
\text { orange } \\
\text { (anionic) }\end{array}$ & 6.5 & 25 & 150 & 30 & $\begin{array}{c}\text { Almost } 100 \% \text { dye } \\
\text { removal }\end{array}$ & [29] \\
\hline $\begin{array}{l}\text { Sewage } \\
\text { sludge (SS) } \\
\text { with } \\
\text { acetone as } \\
\text { the solvent }\end{array}$ & $\begin{array}{c}\text { Liquefaction } \\
\text { at } 260-280 \\
{ }^{\circ} \mathrm{C}\end{array}$ & $\begin{array}{l}\text { The biochar did not } \\
\text { undergo any } \\
\text { special } \\
\text { modifications }\end{array}$ & $\begin{array}{l}\text { Methyl } \\
\text { orange } \\
\text { (MO) } \\
\text { (anionic) } \\
\text { Malachite } \\
\text { green } \\
\text { (MG) } \\
\text { (cationic) } \\
\text { Methylene } \\
\text { blue (MB) } \\
\text { (cationic) }\end{array}$ & 7 & 30 & 150 & 60 & $\begin{array}{ll} & \\
& \text { Acetone based } \\
\text { solution gave } & 53.12 \% \\
& \text { removal. } \\
\checkmark & \text { The bio-chars } \\
\text { were only } \\
\text { effective on } \\
\text { cationic MG } \\
\text { and MB with } \\
\text { removal of } 10- \\
40 \mathrm{mg} / \mathrm{g} \text { and } \\
15-45 \mathrm{mg} / \mathrm{g}\end{array}$ & [30] \\
\hline $\begin{array}{l}\text { Eichhornia } \\
\text { crassipes- } \\
\text { molasses }\end{array}$ & $\begin{array}{l}\text { Pyrolysis at } \\
400^{\circ} \mathrm{C} \text { for } 5 \\
\text { hours }\end{array}$ & $\begin{array}{l}\text { The biochar did not } \\
\text { undergo any } \\
\text { special } \\
\text { modifications }\end{array}$ & $\begin{array}{l}\text { Methylene } \\
\text { blue (MB) } \\
\text { (cationic) }\end{array}$ & 8 & 25 & 125 & 30 & $\begin{array}{l}\text { Maximum } \\
\text { adsorption } \\
\text { capacity of } \\
44.13 \mathrm{mg} / \mathrm{g}\end{array}$ & [31] \\
\hline $\begin{array}{l}\text { Pecan } \\
\text { nutshell }\end{array}$ & $\begin{array}{l}\text { Pyrolysis at } \\
800^{\circ} \mathrm{C} \text { for } 1 \\
\text { hour }\end{array}$ & $\begin{array}{l}\text { The biochar did not } \\
\text { undergo any } \\
\text { special } \\
\text { modifications }\end{array}$ & $\begin{array}{l}\text { Reactive } \\
\text { Red 141 } \\
\text { (RR-141) } \\
\text { (anionic) }\end{array}$ & $2-3$ & 25 & 250 & 80 & 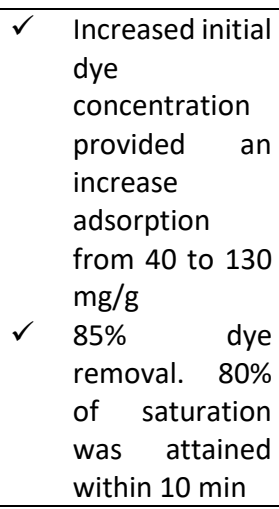 & [32] \\
\hline $\begin{array}{l}\text { Palm Kernel } \\
\text { Shell (PKS) }\end{array}$ & $\begin{array}{l}\text { Pyrolysis at } \\
3500 C \text { in a } \\
\text { rotary kiln } \\
\text { for } 20 \mathrm{~min}\end{array}$ & $\begin{array}{c}\text { The biochar did not } \\
\text { undergo any } \\
\text { special } \\
\text { modifications }\end{array}$ & $\begin{array}{c}\text { Crystal } \\
\text { Violet (CV) } \\
\text { (cationic) }\end{array}$ & 6 & 25 & 100 & 30 & $\begin{array}{l}\checkmark \text { maximum } \\
\text { adsorption } \\
\text { capacity of } \\
24.45 \mathrm{mg} / \mathrm{g}\end{array}$ & [33] \\
\hline
\end{tabular}




\begin{tabular}{|c|c|c|c|c|c|c|c|c|c|}
\hline $\begin{array}{l}\text { Switchgrass } \\
\text { Biochar } \\
\text { modified } \\
\text { by cationic } \\
\text { surfactant } \\
\text { (SB-TTAB) }\end{array}$ & $\begin{array}{l}\text { Pyrolysis at } \\
450^{\circ} \mathrm{C} \text { for } 20 \\
\text { minutes }\end{array}$ & $\begin{array}{l}\text { Biochar added to a } \\
\text { solution of } \\
\text { tetradecyltrimethyl } \\
\text { ammonium } \\
\text { bromide (TTAB) in } \\
\text { ethanol. } \\
\text { Modification goals: } \\
\text { binding a cationic }\end{array}$ & $\begin{array}{c}\text { Reactive } \\
\text { Red (RR- } \\
\text { 195A) } \\
\text { (anionic) }\end{array}$ & 5 & 25 & 150 & 40 & $\begin{array}{ll}\checkmark & \text { Dye removal } \\
& \text { from different } \\
& \text { contaminated } \\
& \text { solutions: } \\
& \text { conc.10/30/50 } \\
& \text { mg/L) } \\
\checkmark & \text { Tap water \%: } \\
10 & -96.61\end{array}$ & [34] \\
\hline & & $\begin{array}{l}\text { surfactant to the } \\
\text { biochar to form } \\
\text { micelle like } \\
\text { structures which } \\
\text { can solubilize dye } \\
\text { within this } \\
\text { structure and } \\
\text { increase the } \\
\text { biochar } \\
\text { capabilities. }\end{array}$ & & & & & & $\begin{array}{l}30-98.82 \\
50-98.76 \\
\checkmark \quad \text { Raw water \%: } \\
10 \text { - } 98.56 \\
30-97.79 \\
50-99.26 \\
\checkmark \quad \text { Wastewater \%: } \\
10-100.00 \\
30-94.83 \\
50-94.24 \\
\checkmark \quad \text { Sea water \%: } \\
10-92.96 \\
30-92.60 \\
50-90.98\end{array}$ & \\
\hline $\begin{array}{l}\text { Kappaphy- } \\
\text { cus alvarezii } \\
\text { seaweed }\end{array}$ & $\begin{array}{l}\text { Pyrolysis at } \\
350^{\circ} \mathrm{C} \text { for } 2 \\
\text { hours }\end{array}$ & $\begin{array}{l}\text { The biochar did not } \\
\text { undergo any } \\
\text { special } \\
\text { modifications }\end{array}$ & $\begin{array}{l}\text { Reactive } \\
\text { blue } 4 \\
\text { (RB4) } \\
\text { (anionic) } \\
\text { Reactive } \\
\text { orange 16 } \\
\text { (RO16) } \\
\text { (anionic) }\end{array}$ & $2-3$ & 30 & 180 & 60 & 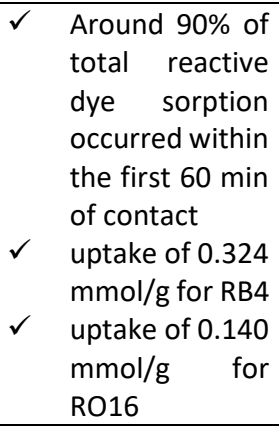 & [35] \\
\hline $\begin{array}{l}\text { Empty fruit } \\
\text { bunch (EFB) }\end{array}$ & $\begin{array}{l}\text { microwave } \\
\text { at } 800 \mathrm{~W} \text { for } \\
30 \mathrm{~min} .\end{array}$ & $\begin{array}{c}\text { EFB particles were } \\
\text { treated chemically } \\
\text { by }\left(\mathrm{FeCl}_{3}\right) \text { before } \\
\text { pyrolysis. Flow of } \\
\text { nitrogen gas } \\
\text { provided iron oxide } \\
\text { magnetite } \\
\text { formation to the } \\
\text { chemical treated } \\
\text { EFB. Modification } \\
\text { goals: biochar with } \\
\text { magnetic features } \\
\text { enable the dye to } \\
\text { be separated by } \\
\text { magnetic } \\
\text { separation } \\
\text { techniques }\end{array}$ & $\begin{array}{c}\text { Methylene } \\
\text { blue (MB) } \\
\text { (cationic) } \\
\text { Orange-G } \\
\text { (OG) } \\
\text { (anionic) }\end{array}$ & $\begin{array}{l}\text { MB: } \\
\text { Both } \\
2 \& 10 \\
\text { OG:2 }\end{array}$ & 25 & 120 & 120 & $\begin{array}{ll}\checkmark & \text { Maximum } \\
\text { adsorption } \\
\text { capacity of } \\
96.68 \% \text { ( } 31.25 \\
\text { mg/g) for MB } \\
\checkmark \quad \text { Maximum } \\
\text { adsorption } \\
\text { capacity of } \\
\text { 90.76\% (32.36) } \\
\text { mg/g for } \\
\text { Orange-G }\end{array}$ & [36] \\
\hline $\begin{array}{l}\text { Empty fruit } \\
\text { bunch (EFB) }\end{array}$ & $\begin{array}{c}\text { Pyrolysis at } \\
400^{\circ} \mathrm{C}\end{array}$ & $\begin{array}{l}\text { The biochar did not } \\
\text { undergo any } \\
\text { special } \\
\text { modifications }\end{array}$ & $\begin{array}{l}\text { Methylene } \\
\text { blue (MB) } \\
\text { (cationic) }\end{array}$ & - & 30 & 150 & 250 & $\begin{array}{l}\checkmark \quad \text { Dye removal of } \\
91 \%, 90 \%, 49 \% \\
\text { and } 36 \% \text { for } 50, \\
100,200 \text { and } \\
300 \mathrm{mg} / \mathrm{L} \\
\text { respectively } \\
\checkmark \quad \text { The EFB } \\
\text { biochar has a } \\
\text { maximum } \\
\text { sorption of } \\
55.25 \mathrm{mg} / \mathrm{g} .\end{array}$ & [37] \\
\hline
\end{tabular}




\begin{tabular}{|c|c|c|c|c|c|c|c|c|c|c|}
\hline $\begin{array}{l}\text { Spirulina } \\
\text { platensis } \\
\text { algae }\end{array}$ & $\begin{array}{l}\text { Pyrolysis at } \\
450^{\circ} \mathrm{C} \text { for } 2 \\
\text { hours }\end{array}$ & $\begin{array}{l}\text { The biochar did not } \\
\text { undergo any } \\
\text { special } \\
\text { modifications }\end{array}$ & $\begin{array}{l}\text { Congo red } \\
\text { dye (CR) } \\
\text { (anionic) }\end{array}$ & $2-7$ & 30 & 120 & 15 & $\checkmark$ & $\begin{array}{l}75-80 \% \text { dye } \\
\text { removal } \\
\text { For different } \\
\text { initial dye } \\
\text { concentrations. } \\
: \\
30,50,70,90,20 \\
0 \mathrm{mg} / \mathrm{l}\end{array}$ & [38] \\
\hline $\begin{array}{c}\text { Chicken } \\
\text { bones (CBB) } \\
\text { after } \\
\text { modificatio } \\
\text { n-MCBB }\end{array}$ & $\begin{array}{l}\text { Pyrolysis at } \\
500^{\circ} \mathrm{C} \text { for } 2 \\
\text { hours }\end{array}$ & $\begin{array}{l}\text { Powdered } \mathrm{CBB} \\
\text { subjected to co- } \\
\text { precipitation with a } \\
\text { mixture of } \mathrm{Fe}^{3+} \text { and } \\
\mathrm{Fe}^{2+} \text { salts. The } \mathrm{CBB} \\
\text { was added into a } \\
\text { solution containing } \\
\mathrm{FeSO}_{4} \times 7 \mathrm{H}_{2} \mathrm{O} \text { and } \\
\mathrm{FeCl}_{3} \times 6 \mathrm{H}_{2} \mathrm{O} \text {. } \\
\text { Modification goals: } \\
\text { biochar with } \\
\text { magnetic } \\
\text { properties for rapid } \\
\text { sorption and a } \\
\text { convenient } \\
\text { recovery. }\end{array}$ & $\begin{array}{l}\text { Rhodamin } \\
\text { e-B (RB) } \\
\text { (basic dye) }\end{array}$ & 10 & 50 & 150 & 120 & $\checkmark$ & $\begin{array}{l}88.5 \% \text { dye } \\
\text { removal for } \\
40 \mathrm{mgL}-1 .(36.2 \\
\mathrm{mg} / \mathrm{g}) \text { after } 120 \\
\text { minutes. } \\
\text { Approximately } \\
96.5 \mathrm{mg} / \mathrm{g} \text { of } \\
\mathrm{RB} \text { was } \\
\text { adsorbed at pH } \\
10 \text { within } 180 \\
\text { min and } \\
\text { reduced to } \\
68.5 \mathrm{mg} / \mathrm{g} \text { in } \\
\text { the presence of } \\
0.5 \mathrm{~g} \mathrm{NaCl} \text {. }\end{array}$ & [39] \\
\hline $\begin{array}{c}\text { Pulp and } \\
\text { paper } \\
\text { sludge (PPS) }\end{array}$ & $\begin{array}{l}\text { Pyrolysis at } \\
108^{\circ} \mathrm{C} \text { for } 2 \\
\text { hours }\end{array}$ & $\begin{array}{l}\text { PPS soaked in a } \\
\mathrm{FeCl}_{3} .6 \mathrm{H}_{2} \mathrm{O} \text { solution } \\
\text { and dried before } \\
\text { being pyrolyzed. } \\
\text { Modification goals: } \\
\text { Reduce porosity } \\
\text { and decrease in } \\
\text { pore volume as a } \\
\text { result of } \\
\text { nanoparticle } \\
\text { impregnation that } \\
\text { will lead to a rapid } \\
\text { dye diffusion into } \\
\text { the active sites } \\
\text { when the particles } \\
\text { organically detach } \\
\text { from the biochar } \\
\text { into the solution }\end{array}$ & $\begin{array}{l}\text { Methylene } \\
\text { blue (MB) } \\
\text { (cationic) }\end{array}$ & 12 & - & - & 40 & $\checkmark$ & $\begin{array}{l}\text { Impregnating } \\
\text { PPS with } \mathrm{Fe}_{2} \mathrm{O}_{3} \\
\text { increased } \\
\text { maximum } \\
\text { adsorption } \\
\text { capacity of the } \\
\text { adsorbent by } \\
\text { more than } 50 \% \\
\text { saturation } \\
\text { points for } \mathrm{BC} \\
(97 \%) \text { and } \mathrm{NC} \\
\text { (98\%) both } \\
\text { occurred at } 5 \\
\text { g/L adsorbent } \\
\text { The maximum } \\
\text { adsorption } \\
\text { capacities } \\
\text { calculated } 33 \\
\text { and } 50 \mathrm{mg} / \mathrm{g} \text { for } \\
\mathrm{BC} \text { and } \mathrm{NC}\end{array}$ & [40] \\
\hline $\begin{array}{l}\text { Korean } \\
\text { cabbage } \\
\text { (KC) }\end{array}$ & $\begin{array}{l}\text { Pyrolysis at } \\
500^{\circ} \mathrm{C} \text { for } 1 \\
\text { hour }\end{array}$ & $\begin{array}{l}\text { The biochar did not } \\
\text { undergo any } \\
\text { special } \\
\text { modifications }\end{array}$ & $\begin{array}{l}\text { Congo red } \\
\text { (CR) } \\
\text { (anionic) } \\
\text { crystal } \\
\text { violet (CV) } \\
\text { (cationic) }\end{array}$ & $\begin{array}{c}\text { CV:11 } \\
\text { CR:7 }\end{array}$ & 30 & 150 & 1400 & $\checkmark$ & $\begin{array}{l}\text { maximum } \\
\text { adsorption } \\
\text { values: } \\
\mathrm{CR} \text { on KC: } \\
95.81 \mathrm{mg} / \mathrm{g} \\
\mathrm{CV} \text { on KC: } \\
1304 \mathrm{mg} / \mathrm{g}\end{array}$ & [41] \\
\hline $\begin{array}{l}\text { Sugarcane } \\
\text { bagasse } \\
\text { (SCB) }\end{array}$ & $\begin{array}{l}\text { Pyrolysis at } \\
400,600,800 \\
{ }^{\circ} \mathrm{C} \text { for } 1 \\
\text { hour. } \\
\text { Best results } \\
\text { for the } 800 \\
{ }^{\circ} \mathrm{C} \text { biochar }\end{array}$ & $\begin{array}{l}\text { The biochar did not } \\
\text { undergo any } \\
\text { special } \\
\text { modifications }\end{array}$ & $\begin{array}{l}\text { malachite } \\
\text { green } \\
\text { (MG) } \\
\text { (anionic) }\end{array}$ & 7.5 & 60 & 10,000 & 51.89 & $\checkmark$ & $\begin{array}{l}100 \% \text { removal } \\
\text { of dye } \\
\text { (conc.:500 } \\
\mathrm{mg} / \mathrm{L} \text { ) for SCB } \\
\text { prepared at } \\
800^{\circ} \mathrm{C}\end{array}$ & {$[42,43]$} \\
\hline
\end{tabular}




\section{Impact}

The sustainability of the textile industry should be addressed across all sectors from fashion designers, manufacturers, product developers and the consumers. The process residuals as waste and wastewater generated requires innovative and affordable technologies and processes for collection and reuse, recycle and upcycle of textile waste (clothing and other textiles), for reducing the consumption of water, energy and chemicals and for treatment of the textile wastewater both in treatment plants and in small dye house industries. The environmental law for the dyeing effluent is in many cases very stringent and this necessitates the need for efficient treatment methods that must follow Zero Liquid Discharge (ZLD) either in common or in non-common treatment plants; however in practice due to the treatment costs it is not always practiced. In addition, even when plants are set for the ZLD, they are still generating hundred tons of hazardous solid waste per day as sludge (residual dyes and waste salts). Efforts should be made also on recovery of the dyes, and other organics from the wastewater before their discharge on to the soil and water bodies, in addition to efficient water treatment by combining novel hybrid membranes and nanotechnologies.

Tamil Nadu is in southern part of India and is engaged in textile processes especially the cotton textile industry. Real textile wastewater effluent from dye houses located in Coimbatore, Tamil Nadu, southern India, was examined for acid-dye removal from wastewater generated when dyeing silk filaments for production of soft silk sarees. The used dye solution from the dye houses is often discharged to the drainage or into the environment due to lack of affordable solutions. These dyes can potentially cause serious environmental damage and health. In our study, optimal conditions were demonstrated for filtration followed by high dye adsorption onto pine derived biochar (both in batch and column studies), and recommendations were suggested for reuse of the water back to the dye houses and for recovery of the biochar post use.

\section{Conclusions}

Different types of biochar were effective in adsorption of dyes from the textile wastewater effluent. Parameters that affect the process are temperature, rotation and mixing speed of the biochar with the dye in batch tests, and reaction time. Another important parameter is the $\mathrm{pH}$ of the biochar-dye suspension. Basic environment $(\mathrm{pH}$ higher than 7) was proven to be ideal for cationic dyes, where acidic environment ( $\mathrm{pH}$ below 7) was proven to be ideal for anionic and acid dyes, with the optimal pH being between 3-4. Different post-production modifications to the biochar can increase the efficiency of the adsorption process and thus improve the entire treatment process; however, the long-term use and reuse of the modified biochar should be monitored.

\section{Conflict of interest}

There are no conflicts to declare.

\section{Acknowledgments}

This research has not been supported by any external funding.

\section{References}

[1] Mekonnen MM, Hoekstra AY. Sustainability: Four billion people facing severe water scarcity; Science Advances 2 (2016), 1-7.

[2] WWF-India; Accenture. Water Stewardship for Industries The need for a paradigm shift in India. (2013), 125.

[3] Ammayappan L, Moses JJ. Study of the characteristics of angora rabbit hair in comparison with medium and fine wool fibers. National Journal of Technology 2 (2006), 50-62.

[4] Islam MM, Khan AM, Islam MM. Textile industries in Bangladesh and challenges of growth. Research Journal of Engineering Sciences 2 (2013), 31-37.

[5] India Brand Equity Foundation. Textiles and Apparel. India Brand Equity Foundation. Available online: https://doi.org/10.1596/9780821399354_ch05. (2017), 45-54.

[6] Natarajan S, Bajaj HC, Tayade RJ. Recent advances based on the synergetic effect of adsorption for removal of dyes from waste water using photocatalytic process, Journal of Environmental Sciences (China) 63 (2018), 201-222.

[7] Chemical Book- Dyes and Pigments www.chemicalbook.com/productcatalog en/16.html

[8] Talukder ME, Kamruzzaman M, Majumder M, Rony MdSH, Hossain M, Das S. Effects of Salt Concentration on the Dyeing of Various Cotton Fabrics with Reactive Dyes. International Journal of Textile Science 6 (2017) 714.

https://doi.org/10.32933/ActaInnovations.37.3•ISSN 2300-5599 • C 2020 RIC Pro-Akademia - CC BY 
[9] Rubeena KK, Reddy PHP, Laiju AR, Nidheesh PV. Iron impregnated biochars as heterogeneous Fenton catalyst for the degradation of acid red 1 dye. Journal of Environmental Management 226 (2018), 320-328.

[10] Mahajan SP. Summer Report Pollution control in process Industries; IIT, Bombay. (2004).

[11] Damas SB, Miranda MIA, Piá AB, Iborra-Clar MI, Iborra-Clar A, Mendoza-Roca JA. Ceramic membrane behavior in textile wastewater ultrafiltration. Desalination 250 (2010), 623-628.

[12] Mostafa D. Waste water treatment in Textile Industries- the concept and current removal Technologies. Journal of Biodiversity and Environmental Sciences 7 (2015), 501-525.

[13] Piaskowski K, Dąbrowska RŚ, Zarzycki PK. Dye Removal from Water and Wastewater Using Various Physical, Chemical, and Biological Processes. Journal of AOAC International 101 (2018), 1371-1383.

[14] Anjum NA, Gill SS, Tuteja N. (Eds.) Enhancing cleanup of environmental pollutants. Enhancing Cleanup and Environmental Pollutants 2017.

[15] Inyang M, Dickenson E. The potential role of biochar in the removal of organic and microbial contaminants from potable and reuse water: A review. Chemosphere 134 (2015), 232-240.

[16] Kimbell LK, Tong Y, Mayer BK, McNamara PJ. Biosolids-Derived Biochar for Triclosan Removal from Wastewater. Environmental Engineering Science 35 (2018), 513-524.

[17] Palansooriya KN, Yang Y, Tsang YF, Sarkar B, Hou D, Cao X, Meers E, Rinklebe J, Kim KH, Ok YS. Occurrence of contaminants in drinking water sources and the potential of biochar for water quality improvement: A review. Critical Reviews in Environmental Science and Technology 50 (2019), 549-611.

[18] Verma M, M'hamdi N, Dkhili Z, Brar SK, Misra K. Thermochemical Transformation of Agro-biomass into Biochar: Simultaneous Carbon Sequestration and Soil Amendment. Biotransformation of Waste Biomass into High Value Biochemicals, Springer New York, (2013), pp. 51-70.

[19] Spear S. What is Biochar? Regeneration International websitehttps://regenerationinternational.org/2018/05/16/what-is-biochar/(2018).

[20] Ronsse F, Hecke SV, Dickinson D, Prins W. Production and characterization of slow pyrolysis biochar: Influence of feedstock type and pyrolysis conditions. GCB-Bioenergy 5 (2013), 104-115.

[21] Roy K, Verma KM, Vikrant K, Goswami M, Sonwani RK, Rai BN, Vellingiri K, Kim K-H, Giri BS, Singh RS. Removal of Patent Blue (V) Dye Using Indian Bael Shell Biochar: Characterization, Application and Kinetic Studies. Sustainability, 10 (2018), 2669.

[22] Zhang XN, Mao GY, Jiao YB, Shang Y, Han RP. Adsorption of anionic dye on magnesium hydroxide-coated pyrolytic bio-char and reuse by microwave irradiation. International Journal of Environmental Science and Technology 11 (2014), 1439-1448.

[23] Salleh MAM, Mahmoud DK, Karim WAWA, Idris A. Cationic and anionic dye adsorption by agricultural solid wastes: A comprehensive review. Desalination, 280 (2011), 1-13.

[24] Ajmal A, Majeed I, Malik RN, Idriss H, Nadeem MA Principles and mechanisms of photocatalytic dye degradation on $\mathrm{TiO}_{2}$ based photocatalysts: A comparative overview. RSC Advances 4 (2014), 37003-37026.

[25] Mishra G, Tripathy M. A critical review of the treatment for decolorization of textile effluent. Colourage 40 (1993), 35-38.

[26] Sewu DD, Boakye P, Woo SH. Highly efficient adsorption of cationic dye by biochar produced with Korean cabbage waste; Bioresource Technology 224 (2017), 206-213.

[27] Rubeenaa KK, Reddya PHP, Laijub AR, Nidheeshc PV. Iron impregnated biochars as heterogeneous Fenton catalyst for the degradation of acid red 1 dye. Journal of Environmental Management 226 (2018), 320-328.

[28] Han L, Xue S, Zhao S, Yan J, Qian L, Chen M. Biochar Supported Nanoscale Iron Particles for the Efficient Removal of Methyl Orange Dye in Aqueous Solutions. PLoS ONE 10 (2015), 1-7

[29] Yu J, Zhang X, Wang D, Li P. Adsorption of methyl orange dye onto biochar adsorbent prepared from chicken manure. Water Science and Technology 77 (2018), 1303-1312.

[30] Leng L, Yuan X, Huang H, Shao J, Wang H, Chen X, Zeng G. Bio-char derived from sewage sludge by liquefaction: Characterization and application for dye adsorption. Applied Surface Science 346 (2015). 223-231.

[31] Mathew M, Desmond RD, Caxton M. Removal of methylene blue from aqueous solutions using biochar prepared from Eichhorrnia crassipes (Water Hyacinth)-molasses composite: Kinetic and equilibrium studies. African Journal of Pure and Applied Chemistry 10 (2016), 63-72.

[32] Zazycki MA, Godinho M, Perondi D, Foletto EL, Collazzo GC, Dotto GL. New biochar from pecan nutshells as an alternative adsorbent for removing reactive red 141 from aqueous solutions. Journal of Cleaner Production 171 (2018). 57-65.

[33] Kyi PP, Quansah JO, Lee CG, Moon JK, Park SJ. The Removal of Crystal Violet from Textile Wastewater Using Palm Kernel Shell-Derived Biochar. Applied Sciences 10 (2020), 2251. 
[34] Mahmoud ME, Nabil GM, El-Mallah NM, Bassiouny HI, Kumar S, A-Fattah TM. Kinetics, isotherm, and thermodynamic studies of the adsorption of reactive red $195 \mathrm{~A}$ dye from water by modified switchgrass biochar adsorbent. Journal of Industrial and Engineering Chemistry 37 (2016), 156-167.

[35] Thivyaa J, Vijayaraghavan J. Single and binary sorption of reactive dyes onto red seaweed-derived biochar: multi-component isotherm and modelling. Desalination and Water Treatment 156 (2019), 87-95.

[36] Mubarak NM, Fo YT, Al-Salim HS, Sahu JN, Abdullah EC, Nizamuddin S, Jayakumar NS, Ganesan P. Removal of Methylene Blue and Orange-G from Waste Water Using Magnetic Biochar. International Journal of Nanoscience 14 (2015), 1-4.

[37] Rebitanim NZ, Ghani WAWAK, Mahmoud DK, Rebitanim NA, Salleh MM. Adsorption of methylene blue by agricultural solid waste of pyrolyzed EFB biochar. Journal of Purity, Utility Reaction and Environment 1 (2012), 376-390.

[38] Nautiyal P, Subramanian KA, Dastidar MG. Adsorptive removal of dye using biochar derived from residual algae after in-situ transesterification: Alternate use of waste of biodiesel industry. Journal of Environmental Management 182 (2016), 187-197.

[39] Oladipo AA, Ifebajo AO, Nisar N, Ajayi OA. High-performance magnetic chicken bone-based biochar for efficient removal of rhodamine-B dye and tetracycline: competitive sorption analysis. Water Science Technology 76 (2017), 373-385.

[40] Chaukura N, Murimba EC, Gwenzi W. Sorptive removal of methylene blue from simulated wastewater using biochars derived from pulp and paper sludge. Environmental Technology \& Innovation 8 (2017), 132-140.

[41] Sewu DD, Jung H, Kim SS, Lee DS, Woo SH. Decolorization of cationic and anionic dye-laden wastewater by steam activated biochar produced at an industrial-scale from spent mushroom substrate. Bioresource Technology 277 (2019), 77-86.

[42] Luo XP, Fu SY, Du YM, Guo JZ, Li B. Adsorption of methylene blue and malachite green 400 from aqueous solution by sulfonic acid group modified MIL-101. Microporous and Mesoporous Materials 237 (2017), 268-274. [43] Vyavahare GD, Gurav RG, Jadhav PP, Patil RR, Aware CB, Jadhav JP Response surface methodology optimization for sorption of malachite green dye on sugarcane bagasse biochar and evaluating the residual dye for phyto and cytogenotoxicity. Chemosphere 194 (2018), 306-315. 